ESJ Social Sciences

\title{
Historical Perspective of the Triple Nexus: The Challenges of Humanitarian, Peacebuilding, and Development Activities
}

\author{
Abdullah Onder Ozkul
}

Development and Humanitarian Aid Worker, Turkey

Doi:10.19044/esj.2021.v17n19p1

Submitted: 18 February 2021

Accepted: 16 June 2021

Published: 30 June 2021
Copyright 2021 Author(s)

Under Creative Commons BY-NC-ND

4.0 OPEN ACCESS

Cite As:

Ozkul A.O. (2021). Historical Perspective of the Triple Nexus: The Challenges of Humanitarian, Peacebuilding, and Development Activities.

European Scientific Journal, ESJ, 17(19), 1. https://doi.org/10.19044/esj.2021.v17n19p1

\section{Abstract}

This paper focuses on discussing development, humanitarian aid, and peace-making notions alongside their historical backgrounds. Different development approaches and methodological dimensions of development were examined through the development process of Turkey. Humanitarian aid was also handled from a historical perspective. The natural and manmade disasters that humanity has faced in recent years and the performed humanitarian interventions were examined. The interaction points for humanitarian aid, development, and the concept of Triple Nexus, a new concept that meets this process, were also examined. According to the chronology of notions, this study first examines the concept of development with the literature research method, and then the literature research results on the concept of humanitarian aid were included. Descriptive research and observation methods, which are among qualitative research methods, were applied in this paper holistically.

Keywords: Economic Development, Humanitarian Aid Organizations, Humanitarian Aid Standards, Triple Nexus, Development History of Turkey, Regional Development, Development with Planning, cross cutting points of Development and Humanitarian Aid

\section{Introduction}

Development is a notion that all positive momentum, from the first days of civilization till now, can gain access to. With the widest perspective 
in human civilization, the touchstones of development could be summarized as follows: start a sedentary life, tame plants and animals, set out agriculture activities, use animal force for agriculture, stock the foods, exchange items, and trade. It also includes the invention of writing, paper, money, geographical discoveries, usage of mine, electricity, the steam engine, industrialization, internet, Internet of Things, etc.

There are many other sub-factors that affect the mentioned development stages such as wars, seasonal changes, religious activities, and societal management systems.

Therefore, it seems that development is a multi-sectoral process, and it is scaled with some global parameters today such as per capita income, average human life, baby mortality rates, and school enrollment rates.

Although, humanitarian aid has shown its first forms with a history of religions, the zakat and the charity mechanisms belong to the concepts of global religions such as Christianity and Islam. The first professional examples of the humanitarian organizations appeared at the end of the 18th century, after World War I. Also, the United Nations and many other professional humanitarian aid organizations have been established after World War II. Recently, humanitarian aid activities have been standardized step by step.

When the basic humanitarian aid activities, which were performed by religious organizations, were excluded, the human civilizations had not developed any structured and systematic humanitarian aid interventions in nature and human-based disasters or illnesses during the long ages.

Informal forms of peacebuilding activities sprung up during the war and disaster periods. However, the formal ones have appeared with the establishment of multinational organizations after World War II. The economic development-based, religious-based, geographic location-based, and security-based organizations may use their power through their networks to mitigate or stop clashes or disputes. Currently, invading a country or announcing war declarations against countries is not a bilateral issue. Nevertheless, all actors consider the opinions of other stakeholders and potential reactions of the multinational organizations. Although all multinational actors are not the direct peacebuilding organizations, their presence might help to ensure peacebuilding naturally and sustain peace keeping.

This paper focuses on underlining the crosscutting points of these concepts and also discusses the potential interaction areas. In historical flow, the studied topics have played crucial roles for the civilization process. Presently, these notions should sustain their presence with ultimate and optimal collaboration with each other.

In this paper, the interaction between the notions was studied with qualitative 
research methods such as descriptive research method and observation method.

\section{Historical Stages of Development and Development Based Multinational Organizations}

The historical processes that humanity goes through determines the human life, welfare level, healthy life span, livelihoods, consumption habits, etc.

Before industrialization, consumption mainly depended on the selfproduction of individuals. However, the industrial revolution food production has boomed, and the consumers have abandoned their producer identities. As a result of the technological inventions, majority of the population began to work in the service sector. More so, these new groups were only consumers. A century ago, the situation was not the same. This is because the producer part of the population exceeded the consumer part.

Settled life, agriculture, use of livestock, industrialization and afterward machinery-based agricultural production, developments in pharmaceutical and chemical industry, automation, internet, etc. can be considered as triggering factors of development processes. Being developed also provides the necessary atmosphere for new inventions and discoveries to occur. In terms of cause and effect relationship, the question of whether development is the cause or effect remains in a controversial area.

The development notion appeared at the global and institutional level in 1945 to eliminate war affects with different international agencies. The global level development-related international organizations include World Bank and IMF (1945) which are Bretton Woods siblings, UNDP (1965), EU (1993), EBRD (1991), and OECD (1961). There are some other organizations that work at limited geographic locations or sectors.

\section{Development Models}

It is possible to see many texts describing development in the literature. Definitions are also related to the management models that authors consider as correct for social development. The economic management model adopted naturally affects the definition of development. Different definitions of development may arise in societies that prioritize liberal and private sector development or societies with planned and intensive state control. The definitions, however, do not have to be the same. Nonetheless, some of the development theories have merged to two options (state-based development or private sector-based development). The mentioned model was known as a Dual Development Model. Currently, the biggest economies of the world adopt this model such as the USA, China, European countries, etc.

According to Kaçanoğlu, communities have made an effort to make 
their living conditions 'better' in the historical process. Improvement in living conditions is usually expressed in the dominant literature with the concept of "development". Therefore, the concept of development has existed since the existence of humanity (Kaçanoğlu, 2019).

The Development Economics notions started after World War II to eliminate and mitigate war damages. However, this was limited to development differences between the countries.

"Many of the people in the world are poor, and they don't even have the United States' standard of living a century ago. The branch of economics that deals with the problems of poor countries called developing countries is development economics." (Dornbusch \& Fischer, 1998)

The meaning of Economic Development has changed in the chronological period. In 1950-1960, the meaning of development was close to economic growth and it was measured with data that reflected economic progress. This perception has been criticized overtime because development cannot be limited to quantitative definitions. During the 1960-1970 period, development notion has been handled with economic dependency. The development concept has also been assessed with dependent economies or countries' terms.

Development theories generally accepted in the literature are as follows:

1. Simple Stage Theory (A.G.B. Fisher- C. Clark)

2. Rostow's Theory of Growth Stages (W.W. Rostow)

3. Kaldor's Growth Laws (N. Kaldor)

4. Pattern of the Industrialization Process (W.S. Hoffmann)

Dual Development Models

1. Development Model with Unlimited Labor Supply (W.A. Lewis)

2. Complementarity Between Agriculture and Industry (Kaldor)

3. Harris Todaro Model Urban unemployment (J.R. Harris - M.P. Torado)

4. Social Dualism (J.H. Boeke)

Balanced and Unbalanced Growth

1. The Big Thrust Theory (P.R. Rodan) Balanced Growth

2. Unbalanced Growth (O. Hirschman)

3. Development Poles (F. Perroux)

4. Polarization Theory (G. Myrdal) (https://ekonomihukuk.com/buyume-kalkinma/kalkinma-teorileri)

Another theory that has recently viewed the concept of development from 
a different perspective is "Human Development Theory". It was developed by the economist Amartya Sen, who won the Nobel Prize in Economics. Sen has taken the discussions one step forward and stated that comprehensive development needs to provide satisfaction to the society in terms of individual rights. When it comes to real development, the private sector and government collaboration is not enough in these modern times.

"Focusing on freedom runs counter to narrower conception of development that identifies development with the growth of gross national product (GNP), increase in individual income, industrialization, technological progress or social modernization. Of course, the increase in GNP or individual revenues can be very important means of expanding the freedom that community members enjoy. However, liberties also depend on other determinants of social and economic arrangements (e.g., education and health care), as well as civil and political rights (for example, the freedom to discuss issues concerning the public and to participate in control). Likewise, industrialization, technological progress or social modernization can contribute significantly to the expansion of individual freedoms. However, freedom depends on other effects. If development enhances freedom, then there is an important reason that requires concentrating on this unifying target rather than a particular list of vehicles or a specially selected tool. Addressing development in terms of the expansion of basic freedom directs attention towards goals that make development more important than some tools that play an important role in this process, among other things." (Sen, 1999)

"There is no single model that its correctness and sustainability was proved in advanced and emerging countries in the field of development. However, there is also no general model about methodology of development. The form and implementing performance of plans prepared for development, depending on political conjuncture of the world and countries, vary. In the periods where central government models have weight, models planned by center have limited auditability in terms of its comprehensiveness and results and the level of success remains very low.

Mentality in development policies has changed together with republican and democratic regimes. Concepts such as regional development, local development, rural development, etc. are 
now having their places in the literature. This change has brought with itself a transition towards a mentality of regional development and regional planning by providing an understanding of planning at central level in the phase of planning in order to get expected efficiency from development moves. In implementations of development, a transition began from central organizations coordinating development process towards institutional structures found on local and watching implementations from first hand." (Özkul, Dincer \& Hacioglu, 2015)

\section{Development in Turkey (1920s-2020)}

Turkey has also embarked on a comprehensive development initiative with the proclamation of the Republic. The Anatolian society, which constantly lost its human resources and economic resources during the Balkan wars, the World War I, and the liberation wars, initiated a restructuring move in every sector such as education, health, state administration, industrialization, banking, and agriculture together with the republic regime after 1923.

The situation analysis of the country in 1920s was presented at the Izmir Economy Congress held before the proclamation of the Republic between February 17 and March 4, 1923. The following decisions taken at the congress can be accepted as the first regulations of the new economic system and country development.

1. It is necessary to establish industry branches whose raw material can be grown domestically.

2. Handicraft and small manufacturing business should be turned quickly to factory or big business

3. The state should gradually become an organ with economic planning and also undertake sectors that cannot be established by private sectors.

4. A State Bank should be established to provide loans to private enterprises.

5. To be able to withstand foreign competition, the industry must be established collectively as a whole.

6. Monopolies established by foreigners should be avoided.

7. Industry encouragement and establishment of national banks should be ensured.

8. The Railways should be linked to the construction schedule.

9. The working people should be called workers, not laborers.

10. The Union right should be 


\section{recognized.}

Most of the decisions taken in this congress have been implemented over time. However, the articles related to agriculture have not been fully achieved even today. As a result, this led to a period of intellectual development, determination of economic inventories, search for models, and implementation to a certain extent, which started with the Izmir Economy Congress. In this period, the possessions and non-possessions of the economy were determined, economic targets were determined, and the foundations of the mixed economy model were prepared (https://tr.wikipedia.org/wiki/\%C4\%B0zmir_\%C4\%B0ktisat_Kongresi).

One of the important decisions that was taken with the congress was that the "laborer" notion will not be used officially, but the "working people" notion will be used instead. Since the laborer refers to daily workers and does not have a regular and trustable job, there is a sociological code that contains humiliation. On the other hand, the "worker" refers to a societal class, particularly in the 1920s. The congress showed that the new Turkey will give special attention to undefined social class.

In the years following the foundation of the Republic, private sectorbased development was prioritized. In other words, the private sector was adopted as the engine of development. Incentive Industry Law, enacted in 1927, is a legal arrangement made within the scope of this understanding. However, the countries' capacity was not suitable for this policy. Society had also previously gone through political stress and wars within the last 20 years. Furthermore, the Ottoman Empire had collapsed. As a result, the community was very exhausted, and the resources had mostly run out. The capital accumulation and the technical infrastructure of the private sector does not have a needed quantity and quality for being a locomotive of the country's development. As a result, the first private sector-based development policy had been turned to state-based development policy.

Due to the impact of the economic crisis in 1929, the economic development attempt of Turkey was slowed down. In 1930s, the Etatism came to the fore as an economic model. Under the Keynesian economic approach on the globe, Turkey carried out economic enhancements with state leadership. Many governmental factory investments were also performed.

As a holistic development movement, alongside the economic regulations, legal regulations (civil law, debt law, commercial law, etc.) and educational regulations (letter reform, establishing national education authority, etc.) were also implemented in this period. These realized arrangements in the social field were the complementary elements of the economic process which resulted in an integrated development.

The First Five-Year Industrialization Plan was created and well- 
implemented between 1934-1938. The Second Five-Years Industrialization Plan was also prepared for the 1939-1944 period. However, it could not be realized due to World War II. Turkey was not a direct side of World War II. Nevertheless, the war-made contraction affected Turkey to a large extent. Turkey did not have any capacity to be part of the active war in these years. World War I had deeply consumed all sources of the country. The republic was established in 1923 and lots of socio-economic revolutions were conducted. The cultivated human capacity, economic, and military capacity was not enough to defend itself across strong allies.

In 1950s, foreign development policies were implemented with American Marshall Aids. Turkey was also in the plans covering 16 countries, based on a strategy to fight Communism. Turkey, positioned itself alongside the United States against the threat of another superpower, Russia. Izmir Economic Congress had been conducted with the motivation of building economic autonomy under the leadership of Ataturk, who was the founder president of Turkey. However, in the 1950s, Ataturk died and his political perception was different from founders of the republic.

1960 was a radical year for Turkey, and the country's government changed hands with a military coup. The following years were known as a planned period in terms of economy and development policies. The 5-year development plan period manifested itself in Turkey's economic history. The State Planning Organization, established in 1961, and the State Statistics Institute, founded in 1962, emerged as institutions with important functions in the planned economic period. The development units were not directly controlled by military officers. Legally, these branches were dependent on the civic Prime Ministry. However, the legal civic politicians were highly hesitant when making regulations about the opinions of the military sides. In other words, the democracy was under the military shadowy.

Unfortunately, the 5-year development plan could not provide the desired efficiency most of the time due to the political turmoil between 1960-1980. There were periods that democratic administration was interrupted such as the military memorandum of 1971, the American sanction of 1974, and the military coup of 1980 . These periods resulted in economic recessions and economic crisis. In 1960, 1971 and 1980, the democracy was wounded with military interventions and all politicians were arrested, imprisoned, defined as politically banned, etc. The first elected civic prime minister had been hanged in 1960. Turkey could also not take the needed international support to defend its democracy. This is still a controversial issue if there were big countries behind the military interventions or not.

January 24, 1980, is an important date for the economic history of Turkey because the economic system of the country was changed. The import substitution industrialization model was abandoned and the export-oriented 
industrialization model was introduced. After 1980, the national economy integrated with the international markets. The foreign exchange freedom started and regional development plans like GAP were scheduled. In this scope, 5 years of national development plans were prepared. However, the development plans could not be put into practice with $100 \%$ efficiency due to the political changes and populist investment approaches. The Liberal economic policies were promptly activated. The politicians could have performed this transition period more professionally if they prioritized their political concerns.

Turkey was faced with high inflation and borrowing between 19902001. This came to the forefront of inefficient public investment and public banks' duty losses (due to populist disbursed loans) undertaken by the Treasury. Thus, this period was finalized with the 1994 and 2001 economic crisis. The 1999 earthquake further increased the fragility of the economy and became a factor that increased the negative impact of the 2001 economic crisis.

Between 2002-2010, there was a global monetary expansion in the world. Additionally, the newly elected government gave priority to the European Union full membership regulations. The negotiations that were carried out in the scope of the EU membership process positively affected the economy. Turkey experienced serious annual economic growth rates such as $7 \%$ and $8 \%$ in these years.

After 2010, the EU full membership negotiations lost motivation because economic growth figures dropped by half, regional economic balances turned negative with the Syrian war, and TL depreciated continuously. Turkey missed the most efficient way of positive status in the period 2002-2010, and could not direct their investments to value-added and productive sectors. On the contrary, highway constructions and low productive investments were prioritized (Yeldan et al., 2013). [Major questions: what policies/factors were responsible for these losses? What role policy-makers played? Why was the democratic opposition suppressed? Who benefitted from this national crisis so that it persisted by repression as documented by international human rights organization and the Turkish Press?]

As a result, Turkey has faced the "Middle Income Trap" and this means annual income per capita did not go above 10.000 USD. The negative sided aggressive movement of the exchange rate, booming unemployment rate, and foreign exchange deficit pressed Annual income per capita to decrease. It dropped to almost 8.000 USD levels. 
Table 1. The periods in Turkey's Economy (Eğilmez, 2019)

\begin{tabular}{|l|l|}
\hline Years & [Specialty] of Period \\
\hline $1923-1929$ & Establishing free trade \\
\hline $1930-39$ & Great Depression, Ottoman Debts, Statism \\
\hline $1940-49$ & Second WW, Famine, Import limitations, Asset tax \\
\hline $1950-59$ & Multi-Party Political life, Liberal Policies, and Marshall Supports \\
\hline $1960-69$ & Planned period, Import substitution \\
\hline $1970-79$ & Petroleum price crises, Cyprus Army Operation, Economic embargo \\
\hline $1980-89$ & Free economic period, Open to foreign bazaar and neoliberal policies \\
\hline $1990-99$ & Open to foreign bazaar, 94 crises and IMF support, Rehabilitation \\
\hline $2000-09$ & 2001 crises, IMF program and support, EU rapprochement liberal policies \\
\hline $2010+$ & Collapse the EU rapprochement, Intervention to market, Politics problems \\
\hline
\end{tabular}

One of the development moves carried out within the scope of EU full membership negotiations was the Development Agencies model. In Turkey, 26 regional development agencies were established in 2005-2010 within 26 statistical regions units. The national level coordination was provided by the General Directorate of Regional Development and Structural Adjustment within the State Planning Organization, which was active in those years.

Development Agencies, which have a state unit status, legally prepared a 5-year regional development plan for their hinterlands. These regional development plans formed the base of the 5-year national development plan prepared by the State Planning Organization (later known as the Ministry of Development).

In addition to preparing a Regional Development Plan, development agencies work to support regional development by declaring grant programs in proportion to their annual budgets allocated from the national budget (Ministry of Development budget).

The principal aim of the agencies was to mitigate the regional development disparities among the sub-regions and ensure regional development by using EU funds. However, they have lost their synergies when Turkey was away from full membership chance to the EU. It seems that although some regulations were realized in the scope of full membership negotiations, some other requested regulations clashed with the political concerns of the Turkish state such as the governmental transparency, legal regulations, decentralizations, etc.

Thus, the regional development agencies have lost their motivation. The grant schemes they implemented with limited annual budgets are inadequate to realize the expected performance from this formation.

\section{Historical Periods of Humanitarian Aid and International Samples}

The first examples of humanitarian aid were practices put forward 
by faith-based organizations. The missionary formations of Christianity and the concept of Zakat of Islam are examples of religious-based humanitarian movements. It is not a criticized issue in this paper, but it was the main starting point of the studied topic.

Consequently, the first and second world wars were the first periods when the rehabilitation of the societies was carried out with a governmental perspective. These studies were of course not human-oriented, but sideoriented. Human-oriented aid activities do not regard national, ethnic, or religious identities. On the contrary, side-oriented activities try to relieve specific groups, ethnicities, believers, etc. In other words, the first humanitarian aid activities aimed to eliminate the bad effects of war from their societies, and not from all the people affected. Hence, they were not impartial.

Along with the multinational organizations, partiality has been overcome, and organizations such as UN, Red Cross, and Red Crescent have handled humanitarian aid processes with a more global vision.

"Having said, the root of aid for a relief mission, known as religious humanitarian aid, goes back to 17th-century philanthropy, though humanitarianism has emerged as a component of the global response to disaster or conflict zone areas. The hardship caused by human-led or natural-based disasters was a significant area for action in humanitarian practice. Several NGOs' were initially formed in response to emergency needs, such as the Red Cross in Italian unification and Oxfam in the Greek famine of 1942. In fact, due to the influence of Cold War politics, much humanitarian aid was confined to the periphery of conflicts, until the 1980s. The rise of multilateral humanitarian aid and the recent shift in grant foreign aid through the 1990s have been accompanied with the thawing of Cold War relations and the humanitarian issue has emerged as a significant aid component. This idea finds a place in the categorization of aid by changing the traditional implication of humanitarian aid. That is to say, even though most of the early practices of humanitarian aid basically ran through the auspices of central states, humanitarian aid today is often practiced without the consent of central states in wartorn countries, such as Afghanistan and Ethiopia. In the name of protecting human rights and liberal values, military interventions to Somalia, Bosnia, and Haiti were launched to address the humanitarian consequences of wars.

In part reflecting this trend, NGO-oriented humanitarian aid has been gradually accelerated, to now become a significant 
player in several humanitarian experiments conducted under the umbrella of the U.N. In parallel to the enhancement of $N G O$-based humanitarian aid, total humanitarian aid has increased. Looking over a more extended period, despite its low share of aid, only increasing from 5\% to $10 \%$ of the total aid in the last 30 years, humanitarian aid has increased at a far faster rate annually than total official aid. For instance, within a decade (from 1990 to 2000) the volume of official humanitarian assistance nearly tripled from $\$ 2$ billion to $\$ 5.9$ billion, which is equivalent to increasing the proportion of $O D A$ (Official Development Assistance) from 5.83 percent to 10.5 percent. In other words, starting from three decades prior to the beginning of the 21th century, there has been a seventeenfold increase in humanitarian aid, whereas ODA has just increased two and a half times. Because of its direct focus on human live, humanitarian aid is treated as one of the fastgrowing types of aid in terms of scope and budget, therefore NGOs and DAC (Development Assistance Committee) donors disbursed over 16,7 billion USD public flow as humanitarian aid in 2016." (Turhan, 2019)

In the Syrian war, for example, Turkey has the largest borderline. There are some historical ties and kin relations among the communities. The open border policy was not a fault decision during the hot clash days in Syria. The Turkish authorities did not forecast such a long-term authority gap in Syria. In the current situation, to solve the refugee problems collaborating with the related international actors will decrease management stress of the Refugee issue.

"While the humanitarian gesture - the will to alleviate the suffering of others - is centuries old and genuinely global, the development of the international humanitarian system as we know it today can be located both geographically and temporally. Its origins are in the Western and especially European experience of war and natural disaster yet it is now active across the world in a range of operations: responding to needs in situations of conflict or natural disasters, supporting displaced populations in acute and protracted crises, risk reduction and preparedness, early recovery, livelihoods support, conflict resolution and peace-building. Over time, the efforts of the most prominent international actors - states, nongovernmental organizations (NGOs), 
international agencies, the Red Cross/Red Crescent Movement - have coalesced into a loosely connected 'system', with links on the level of finances, operations, personnel and values. They work in collaboration, complementarity or competition with other providers of humanitarian assistance, such as affected communities themselves, diaspora groups, religious organizations, national actors, militaries and the private sector." (Davey, Borton \& Foley, 2013)

In recent years, international humanitarian aid operations should be carried out with the collaboration of central governments. The international legal regulations and the presence of multinational organizations, such as the U.N. and E.U., may facilitate the mentioned humanitarian aid operations. The success and effectiveness of activities depend on the quality of operations and the big organizations which implement these activities. As a result, standardization appeared as an indispensable need for humanitarian aid operations. The globally accepted four standards were written as another sentence in the paper.

The NGO's take more roles in the humanitarian aid activities. Globally, U.N. performs a critical role on this ground. The representation role of 193 member countries play a special role. Another big regional multinational organization is E.U., and its quality-based approaches and fiscal power makes it a prominent actor on this ground.

Turkey tries to manage the refugee situation in collaboration with UN organizations and EU organizations.

For example, in the Syria crisis, the Turkey government takes huge funds from the EU organization, i.e., the D.G. ECHO (Directorate-General for European Civil Protection and Humanitarian Aid Operations). Its abbreviation of this fund is ESSN (The Emergency Social Safety Net). This fund is transferred via the KIZILAY (Red Crescent) which is a Turkish-based aid organization. The fund appeals to Syrian Refugees and it has well-defined selection criteria. The NGOs perform a critical role during the implementation disseminated to ESSN among the target group and enlightens the Refugees about the criteria. For more information, visit the web page (https://ec.europa.eu/echo/essn_en).

The state unit and the NGOs are not rivals in this context, but they are complementary bodies. Furthermore, the ESSN fund does not cover all the financial needs of Refugees. However, it is a good implementation example for NGO and state partnership.

According to Heather Rysaback-Smith, underpinning humanitarian action are several major principles of humanitarian law, specifically the rules set out by the Geneva conventions of 1949 . While not directly addressing 
aid organizations, they provide some justification for the provision of relief to civilians and wounded military. They also impose upon the ratifying countries the obligation to allow assistance to be provided. They also insist upon the provision of aid to be impartial, humanitarian, and without favoring one particular side of the conflict, thus strengthening the principles of neutrality and impartiality.

Currently, aid workers face an increasingly complex environment fraught with controversy, political battles, and multiple international organizations. This is a brief introduction to some of the history and principles of humanitarian aid. As conflicts and disasters become more frequent and increasingly geopolitical, adherence to the basic four principles becomes even more important. Alleviating suffering and mitigating the effects of disasters is at the forefront for the provision of aid (Rysaback-Smith, 2015).

The basic four principles of humanitarian aid are Humanity, Neutrality, Impartiality, and Independence.

\section{The Role of Civil Society in Humanitarian Aid}

Humanitarian relief activities started with the individual works of the states in the historical flow. However, the need for multinational humanitarian organizations emerged to respond to global or large-scale problems. Although the states are members of international humanitarian aid institutions, practically, States are not always seen as reliable structures in the eyes of multinational humanitarian organizations. Undoubtedly, the economic and political conjuncture that states were in at that time was the determining factor. In addition, there were concerns for religious entities as well as public demands. The need for other reliable and auditable organizations in cases where states have a problem of trust in the vision of international humanitarian organizations has paved the way for civil society to find a place in the humanitarian sector.

The state is an organization in which politics can be very decisive, and its controllability may be less when compared to civil society. The governmental power may differentiate the implementation with the argument of compliance to national interests. At this point, non-governmental organizations are accepted as transparent formations that can be easily controlled and directed by international organizations. For example, the Turkey government does not ban the humanitarian actors operating in Turkey about the Syria crisis. However, responsible state units observe their activities and request collaboration with the governmental counterparts. The governmental authorities shares the validated foreign NGO/INGO on their web page. There are 135 validated INGOs on the web page of the Ministry of Interior Affairs (https://siviltoplum.gov.tr/turkiyede-faaliyetine-izin-verilen- 
yabanci-stklar).

In 1950s and 1960s, the first examples of multinational humanitarian organizations were seen. In the following years, the NGO's started to show itself actively in the humanitarian sector as a partner of multinational organizations. The United Nations and the European Union have assumed the role of a roof organization in this field, and many non-governmental organizations working in sync with these organizations have specialized in various sub-sectors of humanitarian aid and continued their activities. Moreover, non-governmental organizations were able to find their place within the organizational structures of religious institutions. The funding sources of these organizations, which act with religious motivation, are the organizations they belong to and the donations of the believers.

In addition, some companies and capital owners operating globally, especially in the 2000s, established their own corporate humanitarian organizations or allocated a certain fund from their annual budgets to humanitarian aid. This includes Google, Microsoft, Goldman Sachs, JP Morgan, Johnson \& Johnson, Bill Gates, etc. Tax incentives by governments for such activities are also a factor in this regard.

\section{Intersection of Development and Humanitarian Aid and Triple Nexus}

There is a natural relationship between development and humanitarian work. The dates when both concepts emerged in the historical process are almost the same. The period after the Second World War is the time when both development work and humanitarian aid work emerged within the institutional structures with multinational organizations. This argument may be demonstrated with an example of UN sister organizations. Their establishment dates are close to each other. This was shown in another text in the paper.

The intersection of Development and Humanitarian Aid led to reestablishment, especially after long wars, civil wars, and natural disasters with high destructive dimensions such as World War II. The spread of disadvantaged situations results in a number of negative outcomes such as chronic unemployment, poverty, malnutrition, lack of education, lack of basic health needs, increased infant mortality rates, increased crime rate in the community, etc.

It was almost impossible for countries to come out of the vicious cycle of underdevelopment without radical administrative transformations and without applying widespread conscious development models over time. Societies such as South Korea and Japan succeeded after World War II. Many other countries were badly affected by long wars. An example of such were African countries who struggled to survive by enduring the most negative results of this problematic process. At this point, humanitarian organizations 
carry out their activities to meet the basic needs that people need. This need can sometimes be clean water, clean food, shelter, vaccine, and medicine. In some cases, there may be a need for school, health center, psychological support, and livelihood.

In essence, all needs are the results of underdevelopment and being underdeveloped. Humanitarian organizations and their activities are the short-term response tools of the mentioned problems. For long-term and permanent solutions, broad-basis planned development models should be used.

Undoubtedly, the emergence of development and humanitarian efforts on the same dates was not a result that came about within a plan, but it was a natural result due to the nature of both activities.

Furthermore, the United Nations was created to sustain the conflictfree process after World War II. It has expanded its institutional structure with subsidiaries that specialize in every field in need.

The organization, which was established as an economic cooperation organization between the 6 states with the 1958 Treaty of Rome, has turned into an economic and political formation called the European Union with 27 members and a common currency. The European Union includes suborganizations such as DGECHO, which is focused on humanitarian aid, and economic sub-organizations such as EBRD, which focuses deeply on specialized areas.

In human-oriented organizations such as the EU, sub-working groups emerge as a natural result. Over time, sub-disciplines become specialized in their field by discussing their models and methodologies. Through this process, the sub-organizations are perceived as different study areas as long as they move away from the origin.

In addition, there is an internationally accepted Humanitarian Standards text for Humanitarian Aid studies. Unfortunately, there is no generally accepted model and standard in development. Since humanitarian aid involves more micro-scale, short-term, measurable immediate impact and concrete primary human needs, it is relatively possible to set up and reconcile standards. A development is a process that requires macro analysis, multi-factor, and multi-disciplinary effect which can appear in decades. Also, it has a direct and/or indirect interaction with the political and economic management systems of countries.

A common goal, such as enhancing human well-being, melts both notions into the same pot and they turn each other around.

The excessive institutionalization of international organizations, NGOs working in these areas, and the transformation of the organizational functioning into an excessive bureaucracy has distanced the actors from each other and brought them to a conclusion as if they were separate work areas. 
At this point, actors working in the field of humanitarian aid and actors working in the field of development have begun to rediscover each other around a new concept termed "Nexus".

There is an inverse correlation between development and Humanitarian Aid. The need for Humanitarian Aid organizations emerged after disasters and emergencies and can last until the basic needs are met and human life standards are restored. This process can be considered as the beginning of the main areas conceptually faced by development and humanitarian aid.

The higher the level of development of countries exposed to emergencies such as war, earthquake, fire, flood, etc., the lower the need for humanitarian assistance regarding the incident.

Being developed means that the country has the expected infrastructure, equipment, financial resources, and professional human resources in terms of humanitarian capacity. In other words, humanitarian infrastructure should be considered as one of the basic parameters of development such as education infrastructure, health infrastructure, and transportation infrastructure.

"The idea is not new. The nexus is a continuation of longrunning efforts in the humanitarian and development fields, such as 'disaster risk reduction' (DRR); 'linking relief rehabilitation and development' (LRRD); the 'resilience agenda'; and the embedding of conflict sensitivity across responses. Unlike previous efforts, however, the nexus dialogue goes beyond a programmatic or conceptual approach. It relates to ongoing structural shifts across the aid system that are changing how aid is planned and financed. These will have profound implications for what we do, how we do it and with whom we do it. Along with the opportunities, Oxfam and other aid agencies need to be aware of the potential challenges with a nexus approach. Determining the right mix between humanitarian, development and peace pillars, and the way in which they are integrated, is critical.

However, it is clear that the move towards a humanitariandevelopment-peace nexus has profound implications not just for what organizations do, but how and with whom they do it." (OXFAM, 2020)

Tronc, Grace, and Nahikian have defined this new notion in their study "triple nexus," which is also referred to as the "New Way of Working". This is a policy concept that aims to forge linkages between 
humanitarian, development, and peacebuilding initiatives. The overarching aim of the "triple nexus" is to facilitate collaboration, coordination, information sharing, and joint planning and analysis between practitioners engaged in humanitarian, development, and peacebuilding activities. According to one report, the notion undergirding this concept reveals that peacebuilding, development, and humanitarian actors "all have the same broad objective, i.e., to contribute to the protection and well-being of affected populations and to improve their resilience to external and internal shocks." Furthermore, effectiveness can be stymied, as another report notes specifically of humanitarian action and development work, due to the fact that the "aid architecture is governed by a rigid compartmentalization of humanitarian and development aid". Therefore, "aid is often programmed according to sectoral silos." In addition, 132 Analysts have written that, due to the fact that "the humanitarian development aid architecture is strictly segregated, divided by mandates and rules that were originally designed to meet different kinds of needs," there is a risk that "this rigidity is hampering the aid system's ability to manage risks and rapidly respond to shocks and stress (Tronc, Grace \& Nahikian, 2019).

The Somalia famine in 2016-2018 is a well-known natural disaster. All humanitarian and development actor worked together to eliminate the effects of the disaster. The produced activity report, Supporting longer term development in crises at the nexus Lessons from Somalia, demonstrate the collaboration needs of the sectors.

The successful intervention of the humanitarian sector in averting famine after prolonged drought in 2016 and 2017 fostered greater acknowledgement that humanitarian assistance alone cannot provide a sustainable or cost-effective solution to recurring shocks in Somalia. Donors and the UN community recognise that development efforts should be increased to prevent and build resilience to future economic, climate and conflict-related shocks. Donors are investing in longer term forecasting, anticipatory action, risk reduction and resilience, and, more recently, in recovery, safety nets and social cohesion, but more is needed to move towards sustainable and lasting solutions. This requires substantial development investment and strengthened synergies between humanitarian, development and peace

actors.

(https://reliefweb.int/sites/reliefweb.int/files/resources/Supporting_1 onger_term_development_in_crises_at_the_nexus_Lessons_from_S omalia.pdf)

The other good example of the inter-sector collaboration for humanitarian aid and development sectors is the 3RP. The 3RP stands for 
Regional, Refugee, and Resilience Plan. The Syria Crisis remains the largest displacement crisis in the world, with over 5.6 million registered refugees and over six million people displaced within Syria. The Regional Refugee and Resilience Plan (3RP) offers a strategic, coordination, planning, advocacy, and programming platform for humanitarian and development partners to respond to the Syria crisis at the regional level and in host countries. It comprises one regional plan, with standalone country chapters covering Turkey, Lebanon, Jordan, Egypt, and Iraq. While strategy, planning and programming are country-led processes, regional coherence is pursued to ensure consistency in response planning and implementation. This is done in order to promote common tools, standards, and innovation and to enhance advocacy efforts at global and regional levels (http://www.3rpsyriacrisis.org/).

Another contemporary example of the triple nexus notion is seen in the Syrian crisis, according to World Food Program (WFP) Syria 2020 Annual Country Report. The WFP implements a range of projects under Strategic Outcome 2 of the Syria Interim Country Strategic Plan (ICSP), which is designed to boost livelihoods, reconstitute resilience, and support local communities. These efforts contribute to Sustainable Development Goal (SDG) 2 (Zero Hunger). This is in addition to having significant positive multiplier effects towards SDGs 1 (no poverty), 4 (quality education), and 5 (gender equality). To ensure that interventions have sustainable impacts, WFP made significant shifts in its strategy for Strategic Outcome 2 in 2020 by pivoting from a focus on interventions at the individual and household-level towards community-level asset and value chain support projects. This approach, built on four pillars, contributes to SDG targets 2.1 (end hunger), 2.3 (agricultural productivity), and 2.4 (sustainable food systems). It also aligns directly with the three nodes of the humanitariandevelopment-peace 'triple nexus' by: 1) providing food assistance to save lives and avoid asset depletion; 2) restoring food systems to re-build livelihoods and enable sustainable food security; and 3) promoting social cohesion by strengthening the resilience of local communities in previously conflict-affected areas (https://reliefweb.int/sites/reliefweb.int/files/resources/WFP\%20Syria\%202 020\%20Annual\%20Country\%20Report\%20-\%20PDF\%20version.pdf).

\section{Conclusion}

The two concepts that emerged from the origin of increasing human welfare on the same date developed sub-disciplines, different models, and international standards in their own fields and also rediscovered each other 50-60 years later in order to achieve their common goal. They expressed the intersection points as "triple nexus" by including the concept of 
peacebuilding.

The collaboration need appears particularly in geographies, where humanitarian crises have become chronic over the years. In recent years, Mali, Afghanistan, Rohingya, and Syria were good examples of this. To solve such multi-factorial problems, the actions should be created with common sense. Humanitarian aid, development, peace facility, reconstruction, the establishment of political systems, and short-term emergency assistance should be carried out in harmonization.

Turkey is a relevant stakeholder of the Syrian crisis, since it hosts almost 4 million Syrians. During the first years of crises, urgent humanitarian aid interventions were performed well. In the following years, a permanent social integration requirement has emerged. On the other hand, Turkey has a unique economic problem such as a high unemployment rate and an overly worthless exchange rate. These factors make it difficult to manage the social cohesion. Finalizing their dependency situations and their socio-cultural integrations can now be interpreted as the process is gradually shifting from the focus of humanitarian aid organizations to the focus of development organizations.

COVID-19 is another good example that promptly paralyzed both developed and underdeveloped countries. The health infrastructures of countries passed through a real stress test. The business sector is also faced with bankruptcies and lockdown regulations. Therefore, economic development assistance needs have begun for the private sector. More so, refugees, disabled people, and unemployed people get frontlines because of their vulnerabilities. The humanitarian actors promptly scheduled their response programs. As a result, the humanitarian aid sector and development sector have come together again to increase human welfare one more time.

\section{References:}

1. Davey, E., Borton, J. \& Foley, M. (2013). History of The Humanitarian System Western Origins And Foundations, An Introduction to Humanitarian History, Overseas Development Institute, HPG Working Paper, London, p.1.

2. Dornbusch, R. \& Fischer, S. (1998). Makro Ekonomi (S.Ak ve ark. Çev.), (First Ed.), Mc Graw Hill-Akademi, İstanbul.

3. Eğilmez, M. (2019). The Economy of Turkey, Remzi Bookstore, İstanbul.

4. Kaçanoğlu, M. (2019). “Amartya Sen's Development Perception: Post-Development Approaches Based Study, Doctorate Thesis, Gazi University, 2019.

5. OXFAM (2020).The Humanitarian-Development peace Nexus, http://www.oxfam.org. 
6. Özkul, A.Ö., Dincer, H., \& Hacioglu, U. (2015). “Regional Economic Integration and the Global Financial System" Development Agencies, Grant System And Financial Support For SME's In Turkey, IGI Global, 1st ed., Pennsylvania, p.21.

7. Rysaback-Smith, H. (2015). "History and Principles of Humanitarian Action" Emergency Medicine Association of Turkey, Kare Publishing.

8. Sen, A. (1999). Development with Freedom, transl. Yavuz Alogan, Ayrint1, İstanbul, 1999, p.17-18.

9. Tronc, E., Grace, R., \& Nahikian, A. (2019). "Realities and Myths of the "Triple Nexus" Local Perspectives on Peacebuilding, Development, and Humanitarian Action in Mali" Humanitarian Action at the Frontlines: Field Analysis Series, Harvard Humanitarian Initiatives, p.25.

10. Turhan, Y. (2019). “The Role Of Faith-Based Non-Governmental Organizations In Turkey's Humanitarian Aid Policy And Practice” Doctorate Thesis, Middle East Technical University.

11. Yeldan, E., Taş̧̧i, K., Voyvoda, E., \& Özsan, M.E. (2013). "Turkey On Her Way Out Of Middle-Income Growth Trap" Vol.1., Istanbul, TURKONFED.

12. http://www.3rpsyriacrisis.org/ (06.05.2020).

13. https://tr.wikipedia.org/wiki/\%C4\%B0zmir_\%C4\%B0ktisat_Kongres $\mathrm{i},(02.05 .2020)$.

14. https://ekonomihukuk.com/buyume-kalkinma/kalkinma-teorileri, (02.05.2020).

15. https://reliefweb.int/sites/reliefweb.int/files/resources/WFP\%20Syria $\% 202020 \% 20$ Annual\%20Country\%20Report\%20\%20PDF\%20version.pdf, (03.06.2020). 